\title{
Clay mineralogy of the soils in the south Ecuadorian páramo region
}

\author{
W. Buytaert ${ }^{\mathrm{a}, \mathrm{b}, *}$, J. Sevink ${ }^{\mathrm{c}}$, B. De Leeuw ${ }^{\mathrm{c}}$, J. Deckers ${ }^{\mathrm{a}}$ \\ ${ }^{a}$ Laboratory for Soil and Water Management, Katholieke Universiteit Leuven, Vital Decosterstraat 102, B-3000 Leuven, Belgium \\ ${ }^{\mathrm{b}}$ Programa para el Manejo del Agua y del Suelo, Universidad de Cuenca, Ecuador \\ ${ }^{\mathrm{c} I n s t i t u t e}$ for Biodiversity and Ecosystem Dynamics, Universiteit van Amsterdam, The Netherlands
}

Received 23 February 2004; received in revised form 23 November 2004; accepted 29 November 2004

Available online 4 January 2005

\begin{abstract}
The páramo soils of the mountainous upper Andean region ( $>3300 \mathrm{~m}$ a. s. 1.) of the Rio Paute basin in central Ecuador are characterized by a thick, dark, highly organic epipedon and are classified as Andosols and Histosols. Their high water retention and buffering capacity play a key role in the hydrology of the region, which is subject to land use changes and increased cultivation. In the west (Western Cordillera), the soils are largely formed in the late Miocene and Pliocene volcanoclastic Tarqui formation, while in the east (Central Cordillera) they are formed in an older, mostly intermediate low-grade metamorphic rocks. Ten soil profiles were sampled and studied, using extraction techniques (oxalate and pyrophosphate) and XRD-techniques. Major differences in composition of the clay fractions were found that allow for distinction of three main groups of páramo soils. A first group consists of soils influenced by recent volcanic ashes and dominated by organometallic complexes and with minor but distinct amounts of degraded mica, most probably formed by weathering of primary mica, present in these ashes. The second group comprises soils formed in volcanoclastic material of various Tertiary and earlier formations, containing residual primary and secondary crystalline clay-size minerals, as well as organometallic complexes whose genesis can be linked to the abundant presence of easily weatherable materials in these formations. A third group consists of soils in relicts of Tertiary, highly weathered regolith, formed under humid tropical conditions before the Andean uplift and occurring in the Central Cordillera. These soils contain kaolinite and gibbsite and develop into Histosols in the absence of significant organometallic complexation.
\end{abstract}

(C) 2004 Elsevier B.V. All rights reserved.

Keywords: Clay mineralogy; Organometallic complexes; Páramo; Andosols; Histosols; Ecuador

\section{Introduction}

* Corresponding author. Katholieke Universiteit Leuven, Laboratory for Soil and Water Management, V. Decosterstraat 102, Leuven B-3000, Belgium. Tel.: +32 16329734; fax: +32 16329760 .

E-mail address: wouter.buytaert@agr.kuleuven.ac.be (W. Buytaert).
Soils of the high altitude tropical grasslands or páramo's of the Northern Andes have thick, dark, highly organic epipedons, largely because of the cold and wet climate and the resulting poor decomposition of organic matter. An additional factor is the wide-

0016-7061/\$ - see front matter (C) 2004 Elsevier B.V. All rights reserved. doi:10.1016/j.geoderma.2004.11.021 
spread occurrence of recent volcanic ashes, giving rise to extensive development of Andosols through weathering of these ashes to specific soil compounds that bind organic matter and thus limit decomposition, notably allophanes and other high alumina secondary minerals. A particularly interesting situation occurs in the Rio Paute basin (Cuenca, middle Ecuador) that lies in the border zone of the recent volcanic ash deposits from the major volcanoes in central Ecuador, including the Sanguay and Tungarahua. In the north of this basin, the páramo soils contain a fair amount of volcanic ash and can largely be classified as nonallophanic Andosols, while to the south and east they grade into volcanic ash free Histosols (Buytaert, 2004), developed on sedimentary and low grade metamorphic rocks.

The páramo region is threatened by both erosion and soil degradation due to land use changes and cultivation practices brought about by increasing population pressure and land expansion (Hofstede, 1995). These risks are studied in a joint program on soil and water management in the Rio Paute basin (PROMAS) executed by the Universities of Cuenca (Ecuador) and Leuven (Belgium). These land use changes have a significant impact on the water regulation capacity of the páramo. Soil structure degradation may lead to changes in water retention and hydraulic conductivity (Buytaert et al., 2002; Buytaert, 2004), as well as increased hydrophobicity and water erosion sensitivity (Poulenard et al., 2001). In the Rio Paute basin, the soil physical properties show regional patterns that appear to be connected with differences in soil parent material (Buytaert, 2004).

Soil physical properties are known to be influenced by the mineralogy of the soils concerned, more particularly that of their clay fraction. For the Rio Paute basin, major differences in composition of these clay fractions can be expected to occur in connection with large differences in parent material. However, as will be elucidated further on, very limited information is available on the clay mineralogy of the soils in the area concerned and, in fact, for Ecuador as a whole; the rare existing studies concentrating on selected Andosols. This paper concerns a first regional study of the clay mineralogy of Ecuadorian páramo soils, among which soils that are not developed in recent volcanic ashes, and aims to provide some insight into the range of clay mineral assemblages that may be encountered in this region and environment.

\section{General information}

\subsection{Study area}

The area of study is the paramo of the Rio Paute basin (Fig. 1), which forms part of the Austro Ecuatoriano, the southern Ecuadorian Andes region between $2^{\circ} 15^{\prime}$ and $3^{\circ} 30^{\prime}$ latitude South. Due to its harsh climate, steep topography and poor accessibility, the páramo (above $3300 \mathrm{~m}$ a.s.l.) was an almost uninhabited and desolate area (Fig. 2) that was only used for extensive cattle grazing. Because land pressure rises in the central valley and the páramo is gradually being opened up, intensive grazing and cultivation are increasing.

In Ecuador, the Andes is subdivided into two ridges separated by a tectonic depression: the Western and Central Cordilleras. The Eastern Cordillera forms a much less prominent ridge and only further north, in Colombia, reaches the dimensions of the other Cordilleras. The tectonic uplift of the Cordilleras, which amounts to more than $3000 \mathrm{~m}$, started in the late Miocene and continues until today. The geology of the South Ecuadorian Andes is relatively simple: on the Pacific side, the oldest rocks consist of sedimentary deposits and basic to intermediate volcanic deposits that during the Cretaceous and Early Tertiary were emplaced in a submarine environment, constituting the Macuchi formation. On the continental side, the Central Cordillera has a Palaeozoic and possibly Precambrian basement. Later during the Tertiary, but prior to the start of the tectonic uplift, this basement and the Macuchi formation were covered by a sequence of intermediate and acid volcanic rocks. Once orogenesis started and the Cordilleras originated, volcanoes covered the emerging ridges with pyroclastics, while the interandean depression was filled with a thick sequence of Plio-Pleistocene fluviatile and lacustrine deposits (Barberi et al., 1988; Coltorti and Ollier, 2000). These mostly volcanoclastic sediments are interlayered with lava flows, agglomerates and pyroclasts.

Prior to the major uplift during the Pliocene and Early Quaternary, the rocks of the central range were 


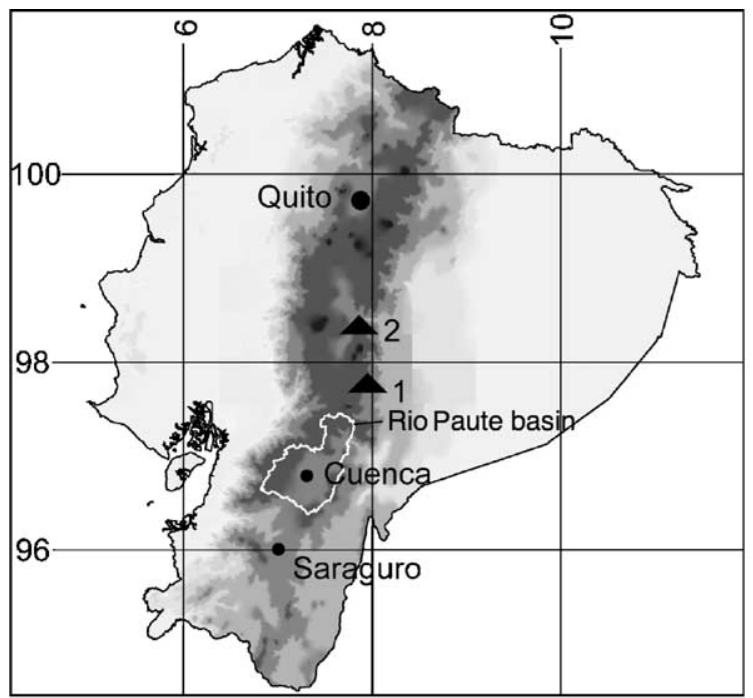

Ecuador
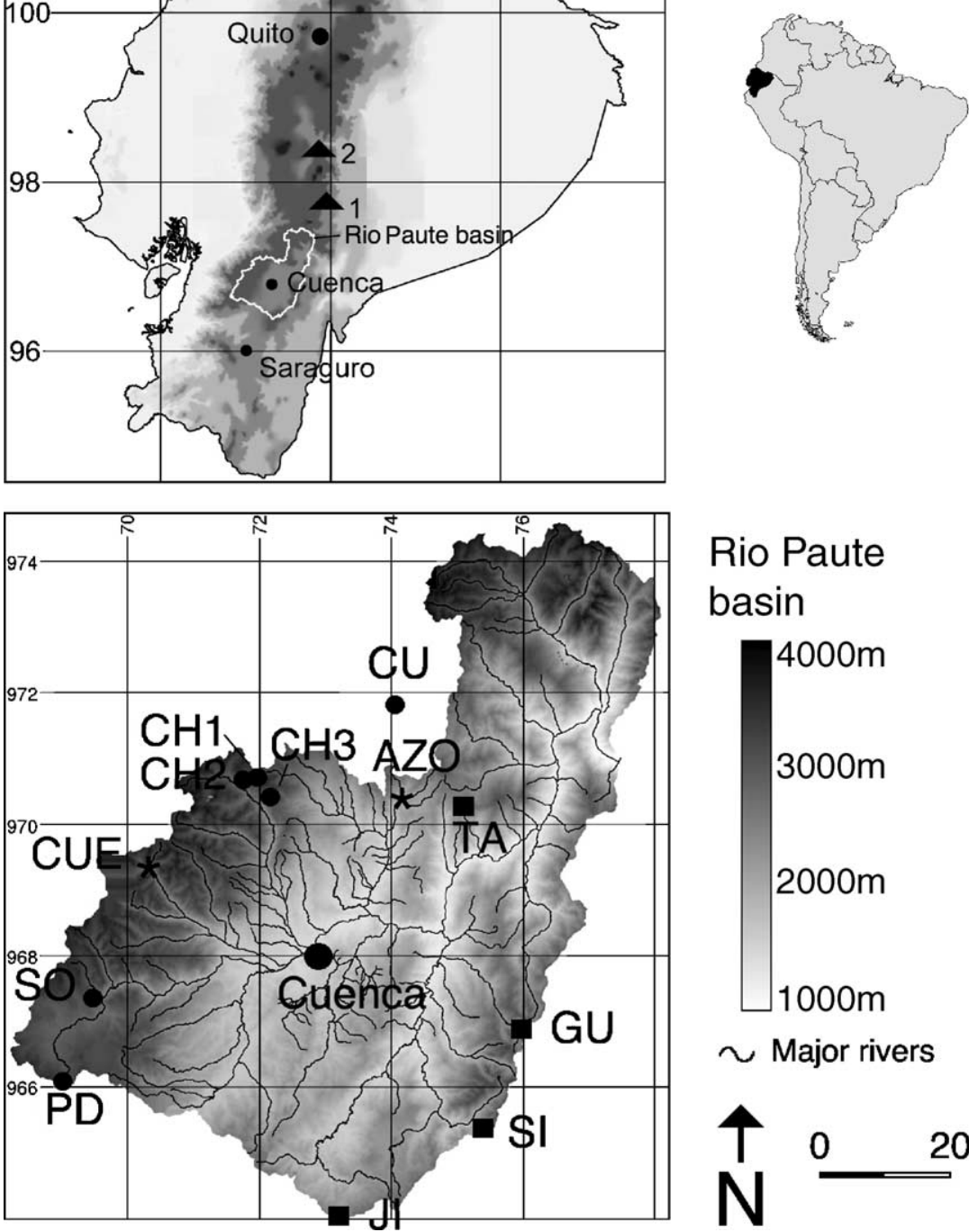

$\sim$ Major rivers

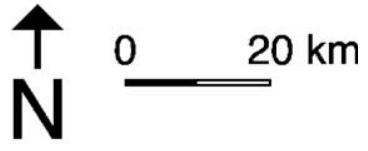

Fig. 1. Location of the Rio Paute basin and the closest active volcanoes (top) and the soil profiles within the basin (bottom). $\bullet$ : profiles of the Western Cordillera transect; $\mathbf{a}$ : profiles of the Central Cordillera transect; *: profiles described and analyzed by Poulenard (2000). 1: Sangay volcano; 2: Tungurahua volcano. Coordinates are in 100000 UTM (upper) and 10000 UTM (lower).

already subjected to prolonged weathering and soil formation under humid tropical conditions, while the Tarqui and Saraguro formations in the western range remained submerged (Barberi et al., 1988). In Central and Southern Ecuador, remnants of the deep regolith or even recognizable soil horizons are still widely encountered on relatively well-preserved summit levels of the Central Cordillera. Lastly, in the Cordilleras granite and granodiorite batholiths were formed, ranging in age from 214 to $10 \mathrm{Ma}$.

Looking in more detail at the Rio Paute basin, the soil parent materials are clearly highly varied (Fig. 3). The upper parts of the Central Cordillera in this basin consist largely of Palaeozoic metamorphic rocks, 


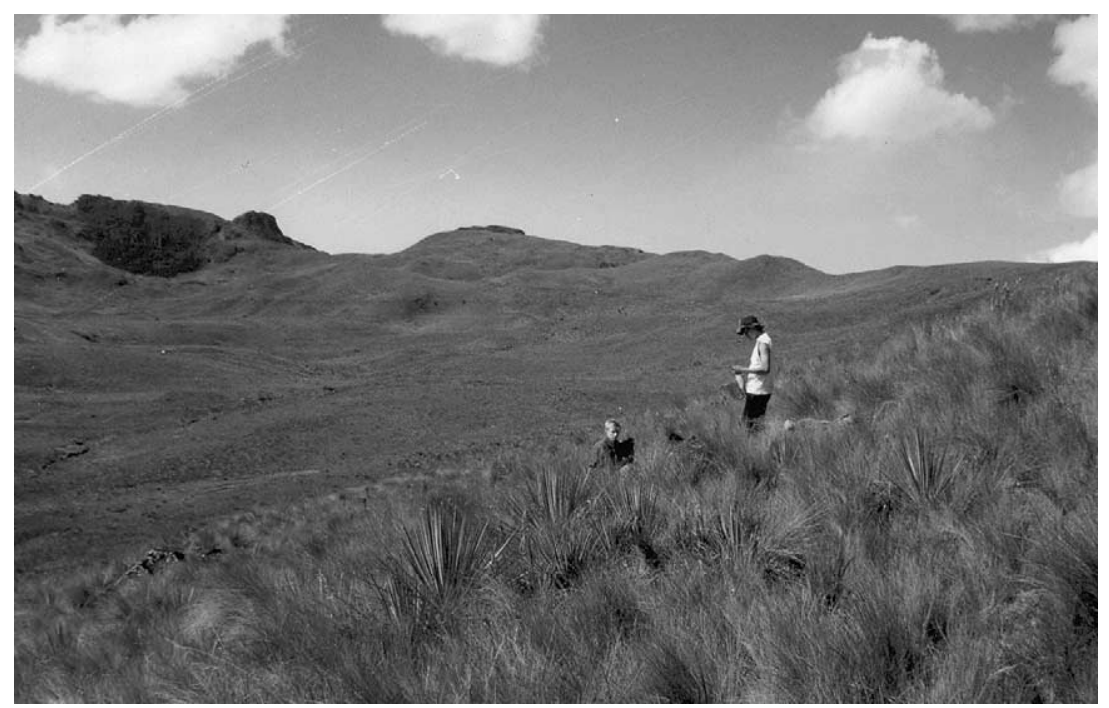

Fig. 2. Typical view of the high Andes páramo ecosystem, characterized by an accidented relief, highly organic soils and a short grass vegetation. The picture shows the surroundings of profile $\mathrm{CH} 3$ (center).
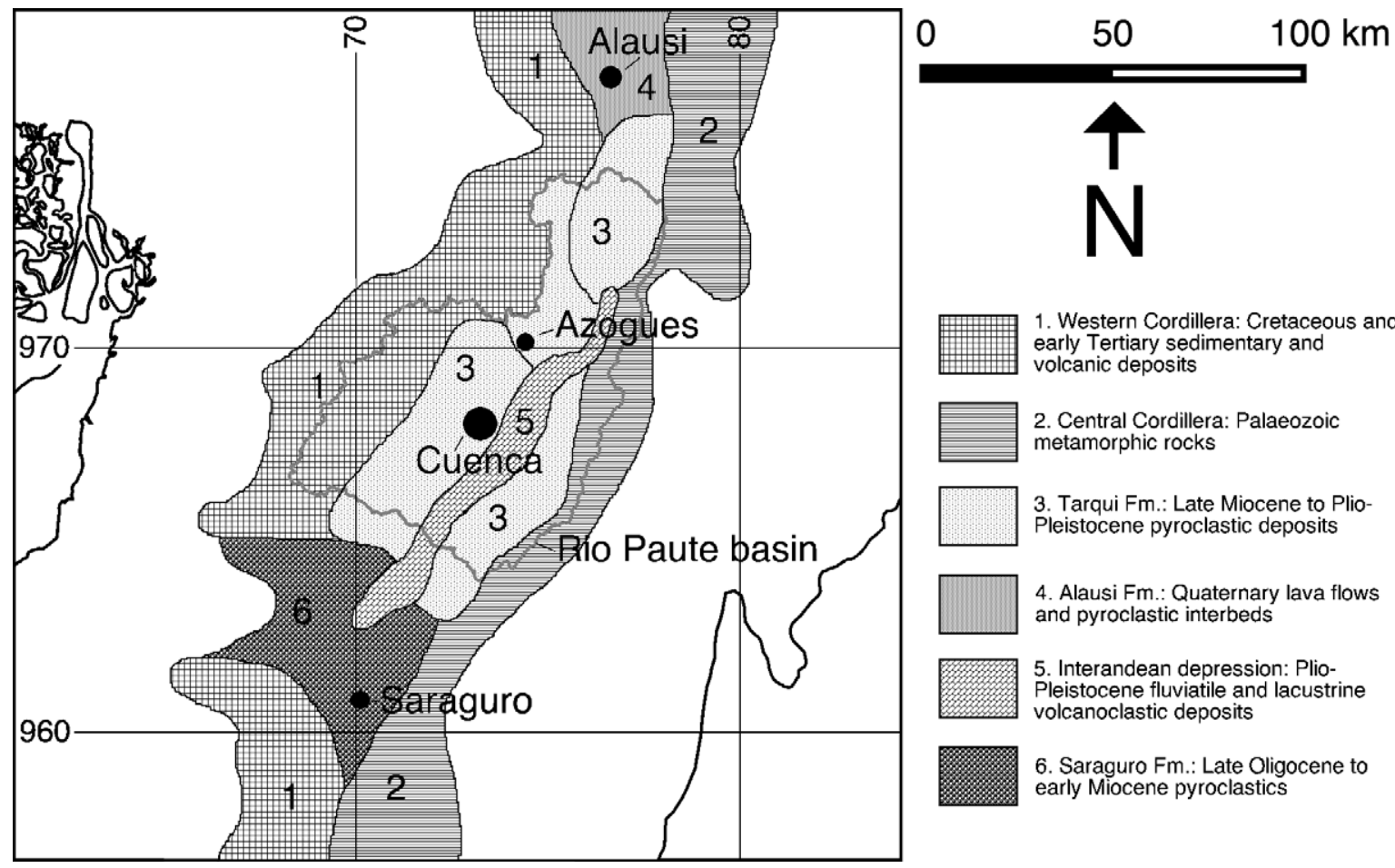

1. Western Cordillera: Cretaceous and early Tertiary sedimentary and volcanic deposits

2. Central Cordillera: Palaeozoic metamorphic rocks

3. Tarqui Fm.: Late Miocene to Plio Pleistocene pyroclastic deposits

4. Alausi Fm.: Quaternary lava flows and pyroclastic interbeds

5. Interandean depression: PlioPleistocene fluviatile and lacustrine volcanoclastic deposits

6. Saraguro Fm.: Late Oligocene to early Miocene pyroclastics

Fig. 3. Schematical representation of the geological formations of the Austro Ecuatoriano (Barberi et al., 1988; Sauer, 1957; Mothes and Hall, 1991). The gray line indicates the limit of the Rio Paute basin. Coordinates are in 10000 UTM. 
dominated by orthogneisses, amphibolites, quartzites, muscovite-biotite schists and a sequence of mica schists and chlorite schists (Coltorti and Ollier, 2000). Deeply weathered regolith is indeed quite common and shows up as variegated or red coloured clays. In the upper parts of the Western Cordillera, the Macuchi formation crops out, which here consists of a thick sequence of pillow lavas and andesitic volcanoclastic deposits.

Younger formations include the Saraguro formation, the Tarqui formation and the Late Quaternary Alausi formation. The late Oligocene to early Miocene Saraguro formation is one of the largest formations of southern Ecuador, extending from Riobamba to Saraguro (Hungerbühler et al., 2002). In the area of study, it consists of intermediate to acid pyroclastics, with andesitic to dacitic tuffs and lava flows prevailing in the lower parts. Coarse coignimbrite breccias and sub-volcanic rocks reflect the near proximity of eruptive centers. Intercalated fluvial and lacustrine sediments abound, indicating aquatic reworking (Coltorti and Ollier, 2000).

The late Miocene to Plio-Pleistocene Tarqui formation is about $300 \mathrm{~m}$ thick and abounds in the northern part of the Paute basin. A large variety of lithologies, including rhyolitic to andesitic volcanic breccias, ashflow tuffs, pyroclastic flows, ignimbrites and many airborne tuffs are observed. The intermediate to acid pyroclastic deposits in the upper part of this formation are often altered to dark red and purple kaolinitic clays (Hungerbühler et al., 2002).

Rocks originating from the Quaternary volcanoes to the north of the basin are limited to thin layers of finegrained ashes that are largely restricted to the northwestern part of this basin. They are of Late Quaternary to Holocene age and belong to the Alausi formation, which forms part of the mostly andesitic Quaternary Northern Volcanic Zone of the so-called Carnegie ridge (Barberi et al., 1988; Monzier et al., 1999).

Previous studies (Buytaert et al., 2002; Buytaert, 2004) showed that in connection with the widespread occurrence of Holocene volcanic ashes, particularly in the Northwestern part of the Rio Paute basin, the páramo soils in the Austro Ecuatoriano are mostly Andosols (Tables 1 and 2) (FAO/ISRIC/ISSS, 1998). However, within the Paute basin, properties of the páramo soils that are connected with their volcanic ash content (andic properties) vary considerably as a function of the distance to the volcanoes of the Northern Volcanic Zone of the Andes and thus to the amount of ashes deposited (see Table 1 and Fig. 1). The only other relevant, but much more specific soil study is that by Poulenard et al. (2003). A summary of the results from these studies is given below.

Irrespective of their parent material, the páramo soils are characterized by very dark epipedons consisting of $\mathrm{Ah}$ and $\mathrm{A}$ horizons with little differentiation, overlying light coloured subsoil (C horizon). In between, often a placic horizon occurs in which case the boundary between top and subsoil is sharp to abrupt. The epipedon contains large amounts of organic material, has a loose, granular to subangular blocky structure and an extremely low bulk density $\left(400 \mathrm{~kg} / \mathrm{m}^{3}\right)$. Extractions with pyrophosphate $(\mathrm{p})$ and with oxalate $\left(_{\mathrm{o}}\right.$ ) show that in most epipedons, the $\mathrm{Al}_{\mathrm{p}}$ content is high and equals the $\mathrm{Al}_{\mathrm{o}}$ content (Table 1), indicating that allophane is absent and that organometallic complexes abound (for details, see methods). $\mathrm{C} / \mathrm{N}$ ratios vary little with an average value of 17.6. This ratio is significantly correlated with the pyrophosphate extractable Al. Given the high content of organometallic complexes, this explains why some $\mathrm{Al}_{\mathrm{p}} / \mathrm{Al}_{\mathrm{o}}$ ratios are higher than 1 . Only some profiles (CU and TA) located further to the north in a drier, monomodal climate and closer to the Sangay and Tungurahua volcanoes, would contain significant amounts of allophane as well as most subsoils. Poulenard et al. (2003) showed that on the whole contents of volcanic glass are low and that this glass, if occurring, is highly weathered.

The water retention capacity is extremely high, reaches values of up to more than $100 \%$ at wilting point and is strongly correlated with the organic matter content. Micropores dominate, while large pores useful for water transmission are scarce. Volumetric shrinkage upon drying correlates with initial void ratio and clay content (Poulenard et al., 2003).

\subsection{Mineralogical composition of clay fractions from páramo soils}

Very limited information is available on the clay mineralogy of Ecuadorian páramo soils and this little information is largely limited to the Andosols. Inventory studies by ORSTOM (e.g. Colmet-Daage et al., 1967a,b) on ash derived high-altitude soils in 
Table 1

Chemical and granulometric characteristics and classification of the studied pedons

Pedon Horizon $\mathrm{pH} \quad \mathrm{PH} \quad \mathrm{pH}$ Sand Silt Clay $\mathrm{SOM} \quad \mathrm{Si}_{\mathrm{o}} \quad \mathrm{Al}_{\mathrm{o}} \quad \mathrm{Fe}_{\mathrm{o}} \quad \mathrm{Si}_{\mathrm{p}} \quad \mathrm{Al}_{\mathrm{p}} \quad \mathrm{Fe}_{\mathrm{p}} \quad \mathrm{Al}_{\mathrm{p}} / \mathrm{Al}_{\mathrm{o}} \quad\left(\mathrm{Al}_{\mathrm{o}}-\mathrm{Al}_{\mathrm{p}}\right) / \mathrm{Classification}$

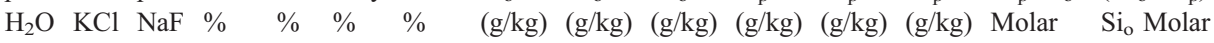

ratio ratio

\begin{tabular}{|c|c|c|c|c|c|c|c|c|c|c|c|c|c|c|c|c|c|}
\hline \multicolumn{18}{|c|}{ Western Cordillera (north to south) } \\
\hline \multirow[t]{3}{*}{$\mathrm{CU}$} & Ah1 & 5.1 & 4.5 & 11.8 & 59 & 25 & 16 & 45.9 & 5.06 & 37.32 & 14.34 & 2.42 & 29.63 & 11.87 & 0.79 & 1.5 & AHA \\
\hline & Ah2 & 4.8 & 4.2 & 11.4 & 40 & 42 & 18 & 44.4 & 1.30 & 24.03 & 11.67 & 0.99 & 23.08 & 9.37 & 0.96 & 0.7 & \\
\hline & A & 5.1 & 4.6 & 12.1 & 83 & 15 & 2 & 31.1 & 12.19 & 49.48 & 12.21 & 2.31 & 19.26 & 8.82 & 0.39 & 2.4 & \\
\hline \multirow[t]{3}{*}{$\mathrm{CH} 3$} & $\mathrm{Ah}$ & 4.6 & 4.2 & 11.1 & 36 & 12 & 52 & 57.2 & 0.51 & 27.01 & 22.00 & 0.48 & 27.43 & 16.57 & 1.02 & n.r. & AHA \\
\hline & A & 4.9 & 4.4 & 11.8 & 27 & 51 & 22 & 67.0 & 1.22 & 48.03 & 15.75 & 1.14 & 51.02 & 13.24 & 1.06 & n.r. & \\
\hline & $\mathrm{C}$ & 4.5 & 4.1 & 11.0 & 65 & 16 & 19 & 39.0 & 0.36 & 3.68 & 0.43 & 0.50 & 3.30 & 0.32 & 0.90 & 1.0 & \\
\hline \multirow[t]{3}{*}{$\mathrm{CH} 2$} & Ah1 & 4.8 & 4.0 & 9.8 & 37 & 44 & 19 & 59.5 & 0.23 & 21.20 & 12.99 & 0.27 & 22.05 & 12.66 & 1.04 & n.r. & AHA \\
\hline & Ah2 & 4.9 & 4.2 & 11.8 & 21 & 50 & 29 & 66.1 & 0.54 & 38.66 & 21.30 & 0.46 & 39.30 & 20.20 & 1.02 & n.r. & \\
\hline & A & 4.7 & 4.3 & 11.6 & 24 & 35 & 41 & 58.9 & 0.80 & 39.40 & 24.07 & 0.65 & 43.78 & 21.66 & 1.11 & n.r. & \\
\hline \multirow[t]{3}{*}{$\mathrm{CH} 1$} & Ah1 & 4.7 & 4.0 & 10.7 & 40 & 43 & 17 & 59.2 & 0.29 & 21.62 & 11.42 & 0.28 & 21.95 & 11.29 & 1.02 & n.r. & AHA \\
\hline & Ah2 & 5.0 & 4.3 & 11.8 & 32 & 30 & 37 & 56.8 & 4.54 & 40.42 & 18.47 & 1.78 & 32.71 & 16.61 & 0.81 & 1.6 & \\
\hline & A & 4.8 & 4.4 & 11.9 & 63 & 17 & 20 & 37.1 & 1.73 & 24.80 & 8.63 & 0.95 & 33.77 & 16.06 & 1.36 & n.r. & \\
\hline \multirow[t]{3}{*}{ SO } & Ah1 & 4.7 & 4.0 & 10.2 & 31 & 31 & 38 & 40.0 & 0.25 & 14.41 & 6.32 & 0.31 & 14.81 & 5.79 & 1.03 & n.r. & AHA \\
\hline & $\mathrm{Ah} 2$ & 4.7 & 4.1 & 11.3 & 34 & 27 & 39 & 35.2 & 0.33 & 16.40 & 6.46 & 0.39 & 17.31 & 6.22 & 1.06 & n.r. & \\
\hline & A & 4.7 & 4.3 & 11.6 & 50 & 16 & 34 & 23.8 & 0.69 & 15.01 & 5.39 & 0.49 & 12.45 & 4.35 & 0.83 & 3.6 & \\
\hline \multirow[t]{3}{*}{ PD } & $\mathrm{Ah}$ & 5.0 & 4.1 & 9.2 & 26 & 42 & 32 & 43.4 & 0.26 & 11.37 & 5.50 & 0.41 & 11.75 & 3.84 & 1.03 & n.r. & $\mathrm{SH}$ \\
\hline & A & 5.0 & 4.2 & 10.3 & 36 & 37 & 27 & 30.9 & 0.56 & 13.26 & 6.39 & 0.61 & 12.86 & 4.52 & 0.97 & 0.7 & \\
\hline & $\mathrm{C}$ & 5.5 & 4.4 & 11.4 & 68 & 16 & 16 & 65.0 & 3.91 & 12.29 & 5.38 & 0.30 & 3.03 & 2.17 & 0.25 & 2.3 & \\
\hline \multicolumn{18}{|c|}{ Eastern Cordillera (north to south) } \\
\hline \multirow[t]{3}{*}{ TA } & Ah1 & 4.8 & 3.9 & 9.6 & 29 & 50 & 22 & 57.0 & 0.25 & 21.20 & 11.43 & 0.20 & 21.38 & 9.07 & 1.01 & n.r. & AHA \\
\hline & Ah2 & 4.9 & 4.2 & 11.7 & 18 & 39 & 43 & 57.3 & 0.75 & 35.86 & 18.19 & 0.49 & 39.27 & 15.82 & 1.10 & n.r. & \\
\hline & A & 4.5 & 4.2 & 11.8 & 19 & 12 & 69 & 51.5 & 0.79 & 37.96 & 19.10 & 0.72 & 37.75 & 17.41 & 0.99 & 0.3 & \\
\hline \multirow[t]{3}{*}{ GU } & $\mathrm{Ah}$ & 4.6 & 3.9 & 9.2 & 62 & 18 & 20 & 23.2 & 0.09 & 4.86 & 9.76 & 0.13 & 4.87 & 7.01 & 1.00 & n.r. & $\mathrm{SH}$ \\
\hline & A & 4.5 & 4.2 & 10.0 & 63 & 21 & 16 & 28.1 & 0.20 & 4.93 & 5.04 & 0.11 & 4.48 & 2.84 & 0.91 & 2.2 & \\
\hline & $\mathrm{C}$ & 4.9 & 4.5 & 10.5 & 67 & 23 & 10 & 25.0 & 0.08 & 1.37 & 1.28 & 0.11 & 1.28 & 1.53 & 0.93 & 1.1 & \\
\hline \multirow[t]{3}{*}{ SI } & $\mathrm{Ah}$ & 4.4 & 3.7 & 8.5 & 25 & 36 & 39 & 50.1 & 0.52 & 10.49 & 7.91 & 0.22 & 9.89 & 6.16 & 0.94 & 1.1 & SH \\
\hline & A & 4.5 & 3.9 & 9.7 & 23 & 31 & 46 & 39.5 & 1.04 & 14.89 & 9.56 & 0.43 & 13.59 & 7.97 & 0.91 & 1.2 & \\
\hline & $\mathrm{C}$ & 5.0 & 4.7 & 11.7 & 79 & 18 & 3 & 10.7 & 6.36 & 21.74 & 6.27 & 0.25 & 2.88 & 0.62 & 0.13 & 2.8 & \\
\hline \multirow[t]{3}{*}{ JI } & Ah1 & 4.1 & 3.4 & 8.7 & 55 & 12 & 33 & 33.9 & 0.32 & 7.22 & 13.99 & 0.18 & 6.35 & 9.39 & 0.88 & 2.6 & $\mathrm{SH}$ \\
\hline & Ah2 & 4.1 & 3.6 & 9.3 & 53 & 14 & 33 & 19.4 & 0.13 & 5.88 & 11.80 & 0.14 & 6.45 & 12.50 & 1.10 & n.r. & \\
\hline & A & 4.2 & 3.7 & 10.0 & 57 & 20 & 24 & 11.5 & 0.05 & 4.39 & 7.44 & 0.07 & 3.63 & 7.25 & 0.83 & 14.6 & \\
\hline
\end{tabular}

AHA-Aluandic Hydric Andosol; SH-Sapric Histosol.

Latin America reveal a general trend that, in addition to varying amounts of allophane and imogolite, contents of residual 2:1 and 2:1:1 clay-size phyllosilicates (illite/vermiculite and soil chlorite) and finegrained quartz increased with increasing rainfall and altitude. The same trend was observed by Mizota and van Reeuwijk (1989) in their study of volcanic ash soils, including several profiles from Ecuador: conspicuous quartz and 2:1 phyllosilicates in the clay fraction with variable amounts of allophane were confined to the high rainfall areas $(4000-5000 \mathrm{~mm}$ per year), whereas those with halloysitic mineralogy were found in drier regions with annual rainfall of 500-1000 mm.
Wada and Kakuto (1985) reported on the formation of a typical form of embryonitic halloysites in nonallophanic Ecuadorian Andosols formed on andesitic ashes. X-ray diffraction patterns of the clays also indicated the presence of the primary minerals cristobalite, feldspars and hornblende, together with large amounts of amorphous material. The latter is common in volcanic ash soils and may consist of allophane, imogolite, $\mathrm{Al}$ and $\mathrm{Fe}$ sesquioxides and organometallic complexes (Shoji et al., 1993).

Poulenard (2000) characterized the mineralogy of 5 Andosols in Ecuador, of which two were located in the Austro-Ecuatoriano: CUE and AZO (Fig. 1). In the clay fraction from the CUE profile, he found minor amounts 
Table 2

Morphological characteristics of the studied pedons

\begin{tabular}{|c|c|c|c|c|c|c|c|}
\hline Pedon & Horizon & Altitude (m) & Slope & Depth (cm) & Colour & $\begin{array}{l}\text { Bulk density } \\
\left(\mathrm{kg} / \mathrm{m}^{3}\right)\end{array}$ & Field texture \\
\hline \multicolumn{8}{|c|}{ Western Cordillera (north to south) } \\
\hline \multirow[t]{4}{*}{$\mathrm{CU}$} & Ah1 & 3700 & $22^{\circ} 30$ & $0-17$ & 10YR1.7/1 & 370 & Loam \\
\hline & Ah2 & & & $17-55$ & 10YR1.7/1 & 380 & Sandy loam \\
\hline & A & & & $55-88$ & $10 \mathrm{YR} 2 / 2$ & 370 & Sandy loam \\
\hline & $\mathrm{C}$ & & & $>88$ & $10 \mathrm{YR} 4 / 3$ & - & Loamy sand \\
\hline \multirow[t]{3}{*}{$\mathrm{CH} 3$} & $\mathrm{Ah}$ & 3600 & $12^{\circ} 40$ & $0-30$ & $7.5 \mathrm{YR} 2 / 1$ & 290 & Sandy loam \\
\hline & A & & & $30-60$ & $7.5 \mathrm{YR} 1.7 / 1$ & 300 & Loam \\
\hline & $\mathrm{C}$ & & & $>60$ & $2.5 \mathrm{YR} 6 / 3$ & 300 & Loamy sand \\
\hline \multirow[t]{3}{*}{$\mathrm{CH} 2$} & Ah1 & 3580 & $2^{\circ} 30$ & $0-20$ & 7.5YR1.7/1 & 290 & Silt loam \\
\hline & Ah2 & & & $20-49$ & 7.5YR1.7/1 & 290 & Silt loam \\
\hline & A & & & $49-70$ & $7.5 \mathrm{YR} 2 / 2$ & 230 & Silt loam \\
\hline \multirow[t]{4}{*}{$\mathrm{CH} 1$} & Ah1 & 3550 & $11^{\circ} 20$ & $0-18$ & 7.5YR1.7/1 & 290 & Loam \\
\hline & Ah2 & & & $18-60$ & 7.5YR1.7/1 & 300 & Silt loam \\
\hline & A & & & $60-78$ & $7.5 \mathrm{YR} 2 / 1$ & 300 & Silt loam \\
\hline & $\mathrm{C}$ & & & $>78$ & 7.5YR4/1 & - & Loamy sand \\
\hline \multirow[t]{4}{*}{ SO } & Ah1 & 3660 & $15^{\circ} 30$ & $0-21$ & 10YR1.7/1 & 470 & Loam \\
\hline & Ah2 & & & $21-42$ & 10YR1.7/1 & 580 & Sandy loam \\
\hline & A & & & $42-62$ & 10YR1.7/1 & 950 & Sandy loam \\
\hline & $\mathrm{C}$ & & & $>62$ & 10YR5/8 & - & Loamy sand \\
\hline \multirow[t]{3}{*}{ PD } & $\mathrm{Ah}$ & 3630 & $18^{\circ} 00$ & $0-12$ & 10YR2/1 & 460 & Loam \\
\hline & A & & & $12-30$ & 10YR1.7/1 & 550 & Sandy loam \\
\hline & $\mathrm{C}$ & & & $30-47$ & 10YR1.7/1 & 760 & Sandy loam \\
\hline \multicolumn{8}{|c|}{ Central Cordillera (north to south) } \\
\hline \multirow[t]{4}{*}{$\mathrm{TA}$} & Ah1 & 3400 & $15^{\circ} 00$ & $3-24$ & 10YR1.7/1 & 310 & Loam \\
\hline & Ah2 & & & $24-58$ & 10YR1.7/1 & 480 & Sandy loam \\
\hline & A & & & $58-74$ & 10YR2/1 & 550 & Sandy loam \\
\hline & $\mathrm{C}$ & & & $>74$ & $10 \mathrm{YR} 5 / 6$ & - & Sandy loam \\
\hline \multirow[t]{3}{*}{ GU } & $\mathrm{Ah}$ & 3350 & $15^{\circ} 00$ & $0-15$ & $7.5 \mathrm{YR} 2 / 1$ & 420 & Silt loam \\
\hline & A & & & $15-40$ & $7.5 \mathrm{YR} 3 / 1$ & 600 & Loam \\
\hline & $\mathrm{C}$ & & & $>40$ & $2.5 \mathrm{YR} 4 / 1$ & 1590 & Sandy loam \\
\hline \multirow[t]{3}{*}{ SI } & $\mathrm{Ah}$ & 3250 & $17^{\circ} 30$ & $0-20$ & 7.5YR1.7/1 & 280 & Loam \\
\hline & A & & & $20-40$ & $7.5 \mathrm{YR} 1.7 / 1$ & 360 & Loam \\
\hline & $\mathrm{C}$ & & & $>40$ & 7.5YR4/6 & 990 & Sandy loam \\
\hline \multirow[t]{4}{*}{ JI } & Ah1 & 3350 & $20^{\circ} 20$ & $0-15$ & 10YR1.7/1 & 340 & Loam \\
\hline & Ah2 & & & $15-34$ & 10YR2/1 & 420 & Sandy loam \\
\hline & A & & & $34-70$ & $10 \mathrm{YR} 3 / 3$ & 610 & Sandy loam \\
\hline & $\mathrm{C}$ & & & $>70$ & $10 \mathrm{YR} 5 / 6$ & - & Sandy loam \\
\hline
\end{tabular}

All pedons were selected under natural grassland vegetation.

of 2:1 or 2:1:1 phyllosilicates such as smectites and chlorites, and no allophane or halloysite. Volcanic glass, hornblende and hyperstene were the main primary minerals present in this profile. The AZO profile was characterized by the presence of kaolinite and illite (clay fraction), and hyperstene-augite sequences as dominant primary minerals (Table 3 ). The nature and provenance of the ashes could not be determined with certainty, because the presence of quartz and the chemical composition of the primary minerals pointed to rather dacitic volcanism, while the volcanic glass and augite contents suggested a more basic volcanism (basaltic andesite). However, considering the location of the profiles, the ashes most probably originated from the Sangay and Tungurahua volcanoes. Lastly, a very recent study is that by Zehetner et al. (2003) on volcanic ash soils in northern Ecuador. Their results conform to those described for Andosols in the general literature (e.g. Wada, 1986) but largely concentrate on the poorly to non-crystalline fractions. 
Table 3

Semi-quantitative composition of the clay fractions: clay minerals

\begin{tabular}{|c|c|c|c|c|c|c|c|c|c|c|c|c|c|}
\hline Pedon & Horizon & $\begin{array}{l}\text { Reg. } \\
\text { Int. }\end{array}$ & Smect & Verm & $\begin{array}{l}\text { Hydrox. } \\
\text { Verm }\end{array}$ & Chlor & $\begin{array}{l}\text { Irr. } \\
\text { Int. }\end{array}$ & Illite & Kaol & Hall & Talc & $\begin{array}{l}\text { Remarks on } \\
\text { interstratifications }\end{array}$ & Crystallinity \\
\hline \multirow[t]{2}{*}{$\mathrm{CU}$} & Ah1 & $?$ & - & - & (x) & - & - & - & $?$ & $?$ & $?$ & & v.1. cryst. \\
\hline & A & $\operatorname{tr} *$ & - & - & (x) & - & - & - & $\operatorname{tr}$ & $\operatorname{tr}$ & - & ${ }^{*}$ mica/verm & v.1. cryst. \\
\hline \multirow[t]{2}{*}{$\mathrm{CH} 3$} & $\mathrm{Ah}$ & $\operatorname{tr*}$ & - & $?$ & - & $?$ & - & - & $?$ & - & - & $*=21 \AA$ & 1. cryst. \\
\hline & $\mathrm{C}$ & $\operatorname{tr} *$ & $\operatorname{tr}$ & $(\mathrm{x})$ & - & $\operatorname{tr}$ & $\mathrm{xx}^{* *}$ & $(\mathrm{x})$ & $x^{b}$ & - & - & $*=25 \AA, * *=7.5-8.5 \AA$ & - \\
\hline \multirow[t]{2}{*}{$\mathrm{CH} 2$} & Ah1 & $\operatorname{tr}$ & - & - & $\mathrm{x}$ & - & $\operatorname{tr}^{*}$ & - & - & $\operatorname{tr}$ & - & $*=12.5-13 \AA$ & m. cryst. \\
\hline & A & - & - & - & $\mathrm{x}(\mathrm{x})$ & (x) & $\operatorname{tr} *$ & - & $\mathrm{x}$ & - & $\operatorname{tr}$ & $*=12.5-13 \AA$ & - \\
\hline \multirow[t]{2}{*}{$\mathrm{CH} 1$} & Ah1 & - & - & - & $\mathrm{x}$ & (x) & - & $\operatorname{tr}$ & $(\mathrm{x})^{\mathrm{b}}$ & - & - & & 1. cryst. \\
\hline & A & - & - & - & $x(x)$ & (x) & - & ? & $\mathrm{x}$ & - & $\operatorname{tr}$ & & - \\
\hline \multirow[t]{2}{*}{ SO } & Ah1 & - & - & - & $\mathrm{x}$ & - & - & $\operatorname{tr}$ & $\mathrm{xxx}$ & - & $\operatorname{tr}$ & & - \\
\hline & A & - & - & - & $\mathrm{x}$ & - & - & $\operatorname{tr}$ & $\mathrm{xxx}$ & - & $\operatorname{tr}$ & & - \\
\hline \multirow[t]{2}{*}{ PD } & $\mathrm{Ah}$ & tr* & $\operatorname{tr}$ & - & $\mathrm{x}$ & - & - & - & $\operatorname{tr}$ & $\operatorname{tr}$ & $\operatorname{tr}$ & *mica/verm & - \\
\hline & $\mathrm{C}$ & $\operatorname{tr} *$ & $\operatorname{tr}$ & - & $x(x)$ & - & - & - & (x) & (x) & - & *mica/verm & - \\
\hline \multirow[t]{2}{*}{ TA } & Ah1 & - & $\operatorname{tr}$ & - & $\mathrm{x}$ & $?$ & $\operatorname{tr} *$ & $\mathrm{x}$ & $x(x)$ & - & $\operatorname{tr}$ & *mica/verm & - \\
\hline & A & - & - & - & $\mathrm{x}$ & $?$ & $\operatorname{tr}^{*}$ & $\mathrm{x}(\mathrm{x})$ & $\mathrm{xxx}$ & - & $\operatorname{tr}$ & $*$ mica/verm & - \\
\hline \multirow[t]{2}{*}{ GU } & $\mathrm{Ah}$ & $\operatorname{tr*}$ & - & - & - & $\mathrm{x}(\mathrm{x})^{* *}$ & $\mathrm{xx}^{*}$ & $\operatorname{tr}$ & $\mathrm{xx}$ & - & $\operatorname{tr}$ & $\begin{array}{l}\text { *ill/(hydrox).verm. } * * \text { primary } \\
\text { dioct. chlorite }\end{array}$ & v.h. cryst. \\
\hline & $\mathrm{C}$ & - & - & - & - & $\mathrm{x}(\mathrm{x})^{* *}$ & - & $\mathrm{xx}^{*}$ & $\mathrm{xx}$ & - & - & $\begin{array}{l}*=\text { muscovite } * * \text { primary } \\
\text { dioct. chlorite }\end{array}$ & - \\
\hline \multirow[t]{2}{*}{ SI } & $\mathrm{Ah}$ & $\operatorname{tr}$ & - & - & $(\mathrm{x})$ & - & - & ? & $\mathrm{x}$ & $\mathrm{x}$ & $\operatorname{tr}$ & & - \\
\hline & $\mathrm{C}$ & $\operatorname{tr}$ & - & - & (x) & - & - & $?$ & $(\mathrm{x})^{\mathrm{b}}$ & - & $\operatorname{tr}$ & & 1. cryst. \\
\hline \multirow[t]{2}{*}{ JI } & Ah1 & $\mathrm{xxx}^{*}$ & - & - & - & $\operatorname{tr}$ & - & - & $\mathrm{xx}$ & - & - & $*$ mica/verm & - \\
\hline & A & $\mathrm{xxx}^{*}$ & - & - & - & $\operatorname{tr}$ & - & $\operatorname{tr}$ & $\mathrm{xx}$ & - & - & *mica/(hydroxy)verm & - \\
\hline
\end{tabular}

Reg. Int.-Regular interstratifications; Smect—Smectite; Verm-Vermiculite; Hydrox. Verm-Hydroxy-interlayered Vermiculite; ChlorChlorite; Irr. Int.—irregular interstratifications; Kaol—Kaolinite; Hall—Halloysite; v.1. cryst.—very low crystallinity; 1-low; m-medium; v.h.—very high, ${ }^{\mathrm{b}}$ — broad peak, tr — traces, $\mathrm{x}$ — clearly present, $\mathrm{xx}$ —abundantly present; *,* - refer to remarks on interstratifications.

The above results, pertaining to studies from Ecuador, are in line with general trends in the composition of clay fractions from Andosols. The most characteristic secondary clay mineral is allophane (Yuan et al., 2000; Parfitt and Kimble, 1989), a name for non-crystalline hydrous aluminosilicate clays with molar Al/Si ratios between 1 and 2 (Parfitt and Furkert, 1980; Wada, 1986). Imogolite $(\mathrm{Al} / \mathrm{Si}=2)$ is another characteristic secondary, tubular aluminosilicate that is described as paracrystalline because of the randomness of the tube orientation (Wada, 1985).

Other characteristic non-crystalline compounds of clay fractions from Andosols are organometallic complexes that may dominate these fractions. Their presence and composition and that of allophane are generally established through extraction techniques with oxalate and pyrophosphate (Parfitt and Hemni, 1980; Parfitt and Wilson, 1985; Shoji et al., 1993).

Smectites and kandites are the main crystalline secondary clay minerals. Weathering conditions in high altitude Andosols are generally unsuited for the genesis of smectites. Among the kandites, halloysite is particularly common and is formed in relatively dry regions. It appears as spheroidal, short tubular or lathshaped particles (Wada, 1986) of 0.04-1 $\mu \mathrm{m}$, or curled flakes (Wada, 1985). Kaolinite is less common and mostly encountered in older soils. Among the crystalline secondary hydr(oxides), ferrihydrite (an amorphous ferric hydroxide) and gibbsite are most common, the latter particularly in older Andosols (Wada, 1986). In case that the parent material contains primary phyllosilicates such as chlorite $(2: 1: 1$ phyllosilicate), biotite or muscovite (2:1 phyllosilicates), these may have weathered to clay-size illite, vermiculite and chlorite. Al-hydroxy interlayering is common, leading to the formation of soil chlorite (Mizota and van Reeuwijk, 1989).

Clay mineralogical studies of Ecuadorian páramo soils that were not developed in volcanic ash are extremely scarce. They seem to be limited to Winckell et al. (1997) who reported that the tropical regolith encountered on summit levels in the Central Cordillera is highly weathered and to Podwojewski (pers. comm. 2002) who observed that páramo soils 
developed in this regolith had a clay-size mineral suite of kaolinite, gibbsite and strongly degraded mica's, including soil chlorite.

\section{Methods}

\subsection{Sites and sampling}

Based on differences in climate and parent material, two transects were selected in, respectively, the Western and the Central Cordilleras (Fig. 1). Profiles $\mathrm{CU}, \mathrm{CH} 1, \mathrm{CH} 2, \mathrm{CH} 3, \mathrm{SO}$ and PD form part of the Western Cordillera transect, while TA, GU, SI and JI are part of the Central Cordillera transect. These transects are north south oriented to provide a gradient in volcanic ash content. Sites were selected in such way that geographical and ecological conditions that could have an influence on soil properties, such as altitude, vegetation, orientation and slope, were as identical as possible (see Table 2). The sites were selected on non-eroded locations, representative for natural páramo, with the typical endemic grass vegetation. Descriptions were according to the FAO soil profile description guidelines (FAO, 1990). Both disturbed and undisturbed soil samples were taken of every genetic horizon of the dark humic layer that dominates the pedons. When only two horizons were present, a third sample was taken from the C-horizon. Undisturbed soil samples were taken in $100 \mathrm{~cm}^{3}$ steel rings. Extensive descriptions of the sites and soils sampled are given in Buytaert (2004). Descriptive and analytical data on the soils are given in Tables 1 and 2 .

\subsection{Analyses}

The undisturbed soil samples were used to estimate bulk density gravimetrically after drying during $24 \mathrm{~h}$ at $105{ }^{\circ} \mathrm{C}$. The disturbed soil samples were air-dried and sieved at $2 \mathrm{~mm}$ to obtain the fine earth fraction. For these fractions, $\mathrm{pH}$ values were established as follows: $\mathrm{pH}_{\mathrm{H} 2 \mathrm{O}}$ in a suspension of 1:2.5 soil/water after $2 \mathrm{~h}$ mechanical shaking; $\mathrm{pH}_{\mathrm{KCl}}$ in a suspension of $1: 2.5$ soil/ $1 \mathrm{M} \mathrm{KCl}$ solution after $2 \mathrm{~h}$ mechanical shaking; $\mathrm{pH}_{\mathrm{NaF}}$ in a suspension of $1 \mathrm{~g}$ soil in $50 \mathrm{ml}$ $\mathrm{NaF}$ solution after 2 min stirring. An extraction with $0.1 \mathrm{M}$ sodium pyrophosphate solution $(1: 100)$ during one night was used to estimate $\mathrm{Al}_{\mathrm{p}}$ and $\mathrm{Fe}_{\mathrm{p}}$ values.
Oxalate extractable $\mathrm{Al}_{\mathrm{o}}, \mathrm{Fe}_{\mathrm{o}}$ and $\mathrm{Si}_{\mathrm{o}}$ were determined by extraction with $0.2 \mathrm{M}$ ammonium oxalate for $4 \mathrm{~h}$ at pH 3 (Mizota and van Reeuwijk, 1989). The granulometry of the samples was established by sieving and sedimentation (pipette method), after removal of organic matter by $\mathrm{H}_{2} \mathrm{O}_{2}$ and dispersion by hexametaphosphate (Van Ranst et al., 1999). It should be stated that for Andosols the recommended method is dispersion using Na-resin (Bartoli et al., 1991), but due to technical limitations (in Ecuador) this was not possible. Therefore, the granulometric data should be treated with care. Organic carbon was determined by element analyser using the Dumasmethod on an EAS varioMax N/CN (Elt, Gouda, The Netherlands).

Clay fractions were separated by sedimentation after removal of organic matter with $\mathrm{H}_{2} \mathrm{O}_{2}$ and oxalate extraction (Van Reeuwijk, 2002). It should be stressed that this extraction not only removes amorphous compounds, but may to some extent affect 'crystalline' compounds as well, such as hydroxyinterlayers in smectites and vermiculites or poorly crystalline gibbsite and halloysite. However, its major aim in this case was to remove amorphous and poorly crystalline substances that hamper X-ray diffraction analysis. Moreover, all samples received the same treatment, thus allowing for comparison of results between individual samples.

For diffractograms use was made of well-oriented clay, obtained through sedimentation on ceramic tiles. Sample pretreatment followed standards used for Xray analysis of clay fractions as, for example, described by Brown et al. (1972) and includes: (a) $\mathrm{Mg}$-saturated, air dried at 55\% relative air humidity; (b) Mg-saturated, glycol solvated; (c) K-saturated, airdried at $55 \%$ relative humidity; (d) K-saturated, heated in oven at $300{ }^{\circ} \mathrm{C}$ and (e) K-saturated, heated in oven at $550{ }^{\circ} \mathrm{C}$. Samples were scanned from $2^{\circ} 2 \theta$ to $30^{\circ} 2 \theta$, using $\mathrm{CuK} \alpha$ radiation. Additional analyses were carried out on non-oriented fractions by a Guinier-type camera using $\mathrm{CoK} \alpha$ radiation. The mineralogical composition of the samples was estimated from peaks and their height in the diffractograms and from the reflection intensities on the films (Borchardt, 1989). The degree of crystallinity of individual minerals was inferred from the ratio between peak height and width for first or second order reflections (d001/d002) and estimated semi- 
quantitatively by comparison with standard samples (see for example Dixon and Weed, 1989). As regards more detailed identification of kaolin minerals, we refrained from intercalation with dimethyl sulphoxide or similar substances to differentiate between kaolinite and dehydrated halloysite and based our identification on the sharpness and asymmetry of the d001 peaks (see Wilson, 1987).

\section{Results}

The abundance and composition of 'non-crystalline' materials can be derived from Table 1, in which results from oxalate and pyrophosphate extractions are presented. It should be realized that these data pertain to fine earth fractions and not to clay fractions.

As is illustrated by the $\mathrm{Al}_{\mathrm{p}} / \mathrm{Al}_{\mathrm{o}}$ ratio, which in nearly all samples is close to unity, organometal complexes of $\mathrm{Al}$ (and $\mathrm{Fe}$ ) abound and allophane occurs in very minor amounts only (Parfitt and Wilson, 1985). Differences between soils from the Western and those from the Central Cordillera are considerable, with much higher contents of extractable aluminium, silica and iron in the Western Cordillera, particularly in the profiles $\mathrm{CU}, \mathrm{CH} 3$, $\mathrm{CH} 2, \mathrm{CH} 1$. Profiles SO, PD and TA hold an intermediate position, while those of the Central Cordillera exhibit low values. Overall differences between the Western and Central Cordillera are presented in Table 4 and evidence that Andic properties are much more prominent in the Western Cordillera, as already described by Buytaert (2004).

Table 4

Mean characteristics of the West and Central Cordillera

\begin{tabular}{|c|c|c|c|}
\hline Parameter & Mean west & Mean central & $P$ \\
\hline $\mathrm{pH}\left(\mathrm{H}_{2} \mathrm{O}\right)$ & 4.83 & 4.46 & $<0.001$ \\
\hline $\mathrm{pH}(\mathrm{KCl})$ & 4.23 & 3.87 & $<0.001$ \\
\hline $\mathrm{pH}(\mathrm{NaF})$ & 10.9 & 9.85 & 0.008 \\
\hline Sip $(\mathrm{mg} / \mathrm{g})$ & 1.04 & 0.26 & 0.007 \\
\hline $\mathrm{Al}_{\mathrm{p}}(\mathrm{mg} / \mathrm{g})$ & 25.4 & 14.8 & 0.02 \\
\hline $\mathrm{Al}_{\mathrm{o}}(\mathrm{mg} / \mathrm{g})$ & 28.6 & 14.8 & 0.01 \\
\hline $\mathrm{Al}_{\mathrm{o}}+0.5 \mathrm{Fe}_{\mathrm{o}}(\mathrm{mg} / \mathrm{g})$ & 35.4 & 20.5 & 0.01 \\
\hline Silt (\%) & 38.8 & 23.3 & 0.005 \\
\hline Clay (\%) & 24.9 & 36.3 & 0.04 \\
\hline $\mathrm{pF}=4.2(\%)$ & 70.4 & 25.6 & 0.005 \\
\hline
\end{tabular}

The $P$ value indicates the chance of equal means.
In this Western Cordillera, additionally, Andic properties become less evident going south.

Since the XRD analyses concern clay fractions from which 'amorphous' compounds have been removed, these clay fractions consist of 'crystalline' primary and secondary clay-size minerals. Nevertheless, the crystallinity of the phyllosilicates as based on the ratios between height and width of d001 or d002 peaks varies from relatively poor in most samples from the Western Cordillera to overall well in the Central Cordillera (see Table 3). This trend parallels the observed trend in contents of noncrystalline material described above, at the same time illustrating that the distinction between 'crystalline' and 'amorphous' compounds as based on oxalate extractions is rather arbitrary.

Results from the X-ray analyses are given in Table 3 (phyllosilicates) and Table 5 (other minerals). As illustrated by Table 3, a wide range of phyllosilicates occurs. These include, in addition to $1: 1$ minerals (kaolinite and halloysite), various 2:1 and 2:1:1 clay minerals. X-ray camera results (not shown here) indicate that these latter minerals are dioctahedral (based on hkl 060 reflections). Smectite is rare, only occurring in traces. In several samples, interstratifications of mica-vermiculite type are common or even abound. Additionally, in many samples interstratified and hydroxy-interlayered clay minerals occur of which the identification is based on their behaviour under the various treatments. Main types encountered and their characteristics are described in more detail below.

Peaks indicative for regular interstratifications are sharp and occur at higher $2 \theta$ values, and species involved can be identified by their behaviour under various treatments. In our samples, such peaks are relatively rare and mostly weak to very weak with the exception of profile JI, the most common species being a mica-vermiculite interstratification, which in addition to a first order peak at around $23.5 \AA$ in $\mathrm{Mg}$ saturated and glycerolated samples even produces a second order peak at about $12 \AA$. Identification of the latter species is based on the occurrence of these peaks, and their collapse upon K-saturation and heating. In some samples, reflections occur at $21 \AA$, but species involved could not be identified with certainty. They do not fully collapse after saturation with $\mathrm{K}$ and heating, suggesting that hydroxy-interlayering plays a role (Fig. 4a). 
Table 5

Semi-quantitative composition of the clay fractions: non-clay minerals

\begin{tabular}{|c|c|c|c|c|c|c|c|c|}
\hline Pedon & Horizon & Quartz & Cristobalite & Hematite & Gibbsite & Goethite & Feldspar & Heulandite \\
\hline \multicolumn{9}{|c|}{ Western Cordillera (north to south) } \\
\hline \multirow[t]{2}{*}{$\mathrm{CU}$} & Ah1 & $\operatorname{tr}$ & $(\mathrm{x})$ & $\operatorname{tr}$ & - & - & $\mathrm{x}$ & - \\
\hline & A & $\operatorname{tr}$ & (x) & $\operatorname{tr}$ & - & - & $\mathrm{x}$ & - \\
\hline \multirow[t]{2}{*}{$\mathrm{CH} 3$} & $\mathrm{Ah}$ & $\mathrm{x}$ & $\mathrm{x}$ & $\operatorname{tr}$ & - & - & $\operatorname{tr}$ & - \\
\hline & $\mathrm{C}$ & (x) & $\operatorname{tr}$ & - & - & - & $\operatorname{tr}$ & - \\
\hline \multirow[t]{2}{*}{$\mathrm{CH} 2$} & Ah1 & $\mathrm{x}$ & $x(x)$ & (x) & - & - & - & - \\
\hline & A & $x(x)$ & $x(x)$ & (x) & - & - & - & - \\
\hline \multirow[t]{2}{*}{$\mathrm{CH} 1$} & Ah1 & $x(x)$ & (x) & - & - & - & $\operatorname{tr}$ & - \\
\hline & A & $\mathrm{xx}$ & $\mathrm{x}$ & (x) & - & - & $\mathrm{x}$ & - \\
\hline \multirow[t]{2}{*}{ SO } & Ah1 & $x(x)$ & $\operatorname{tr}$ & $\operatorname{tr}$ & - & - & $\mathrm{x}$ & - \\
\hline & A & $x(x)$ & $\operatorname{tr}$ & $\operatorname{tr}$ & - & - & $\mathrm{x}$ & - \\
\hline \multirow[t]{2}{*}{ PD } & $\mathrm{Ah}$ & - & - & - & - & - & - & $\mathrm{x}$ \\
\hline & $\mathrm{C}$ & - & - & - & - & - & - & $\mathrm{xx}$ \\
\hline \multicolumn{9}{|c|}{ Central Cordillera (north to south) } \\
\hline \multirow[t]{2}{*}{$\mathrm{TA}$} & Ah1 & $\mathrm{x}$ & $\mathrm{x}$ & $\operatorname{tr}$ & $(\mathrm{x})$ & - & - & - \\
\hline & A & $\mathrm{x}(\mathrm{x})$ & $\mathrm{x}$ & $\operatorname{tr}$ & (x) & - & - & - \\
\hline \multirow[t]{2}{*}{ GU } & $\mathrm{Ah}$ & $\operatorname{tr}$ & - & - & - & - & - & - \\
\hline & $\mathrm{C}$ & $\operatorname{tr}$ & - & - & - & - & - & - \\
\hline \multirow[t]{2}{*}{ SI } & $\mathrm{Ah}$ & $(\mathrm{x})$ & $\mathrm{xx}$ & - & $\mathrm{x}$ & - & - & - \\
\hline & $\mathrm{C}$ & $\mathrm{xx}$ & $\mathrm{xx}$ & - & $\mathrm{x}$ & - & - & - \\
\hline \multirow[t]{2}{*}{ JI } & Ah1 & - & - & - & $x(x)$ & - & - & - \\
\hline & A & - & - & - & $\mathrm{x}(\mathrm{x})$ & $\operatorname{tr}$ & - & - \\
\hline
\end{tabular}

tr-traces, $\mathrm{x}$ - clearly present, $\mathrm{xx}$ - abundantly present.

Irregular interstratifications show up by broad peaks at intermediate $2 \theta$ values of their components, the value being determined by their composition. In some of our samples they abound, such as those of profile CH3. Diffractograms of that sample are shown in Fig. $4 \mathrm{~b}$ and demonstrate that these interlayers most probably consist of an assemblage of kaolinite (collapse of peak after heating to $550{ }^{\circ} \mathrm{C}$ ) and some 2:1 clay mineral species (illite or vermiculite), based on the occurrence of distinct $8-9 \AA$ reflections independent of pretreatment up to $300{ }^{\circ} \mathrm{C}$ and their disappearance upon heating to $550{ }^{\circ} \mathrm{C}$. In sample GU, they most probably are composed of an interstratification of illite and slightly hydroxy-interlayered vermiculite. This is evidenced by a quite broad peak around 11.5 A upon Mg saturation and glycol solvation, its partial collapse upon $\mathrm{K}$ saturation and full collapse of this peak upon heating to $300{ }^{\circ} \mathrm{C}$ (Fig. $4 \mathrm{c}$ ).

Hydroxy-interlayering shows up as relatively broad d001 peaks and their incomplete collapse upon heating. The extent of hydroxy-interlayering varies and is reflected in the peak behaviour at various temperatures. Sample TA-A exemplifies a relatively weak hydroxy- interlayering, while in sample $\mathrm{CH} 2-\mathrm{A}$ this is much more prominent, as is illustrated by Fig. $4 \mathrm{~d}$.

As to the kaolin minerals, their d001 reflections vary from sharp and at about $7.0 \AA$ to broad, asymetric and at slightly higher value (up to 7.27.3). Halloysite is tentatively identified by the latter characteristics, while kaolinite usually gives sharp, symmetric peaks. This formed the basis for the distinction between these species in Table 3. However, it should be stated that this distinction is tentative and could be improved by further analysis employing intercalation methods. Examples are given in Fig. 4, illustrating the wide range in properties of kaolin minerals in our samples (SI-Ah shows the presence of two kaolin species) (Fig. 4e).

Based on the above described criteria and characteristics, results for the transects can be summarized as follows:

In the Western Cordillera, the CU samples, although very poorly crystalline, contain some regular interstratifications of a mica-vermiculite type, identified by a $24 \AA$ reflection in the $\mathrm{Mg}$ saturation sample and a reflection of lower value upon $\mathrm{K}$ saturation. The 
a

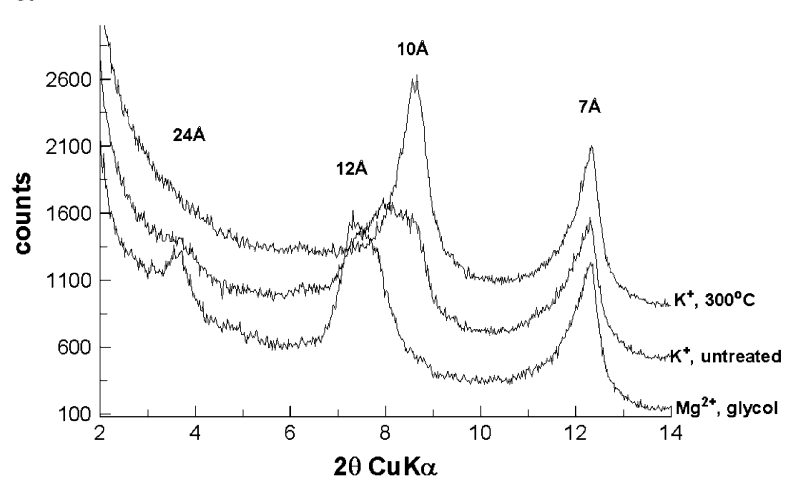

C

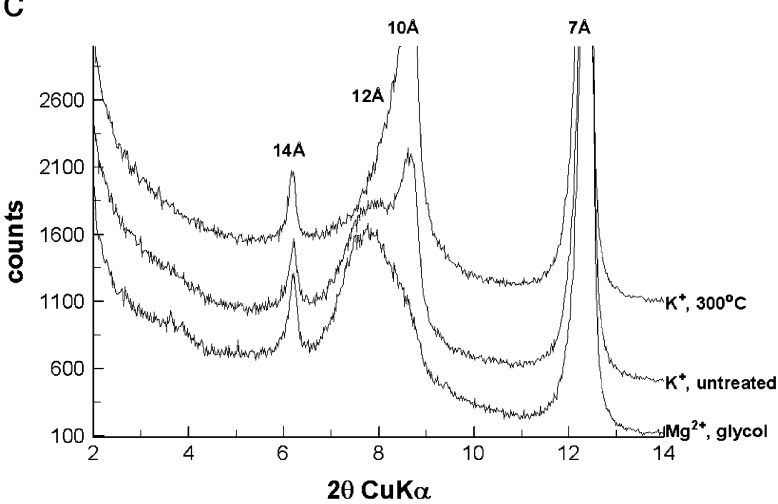

e

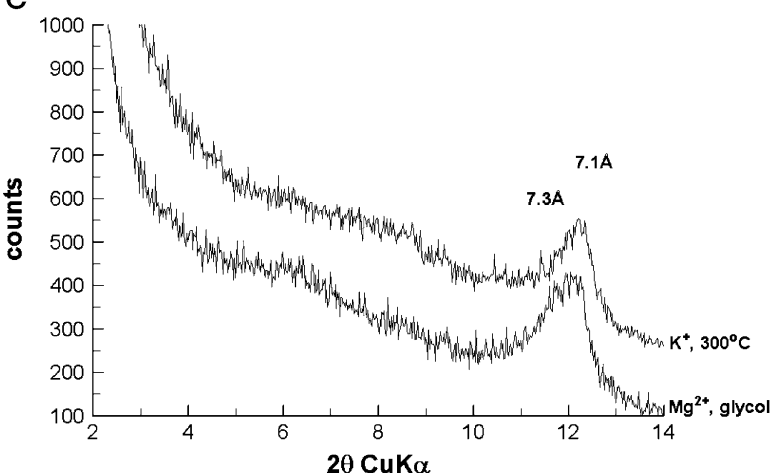

b

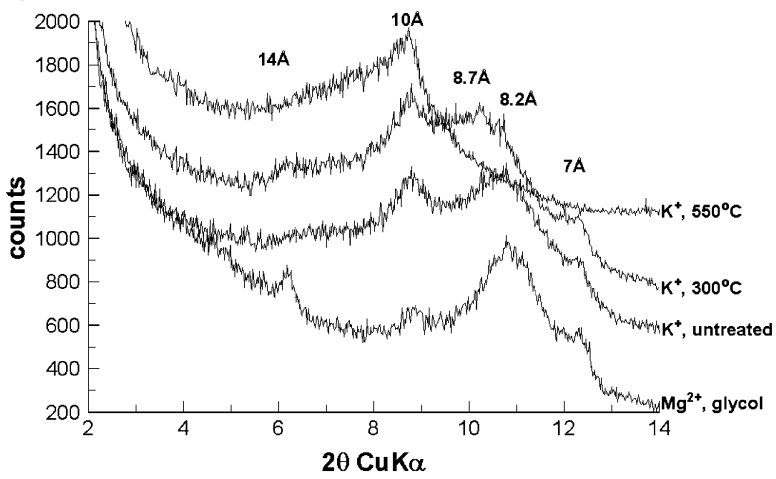

d

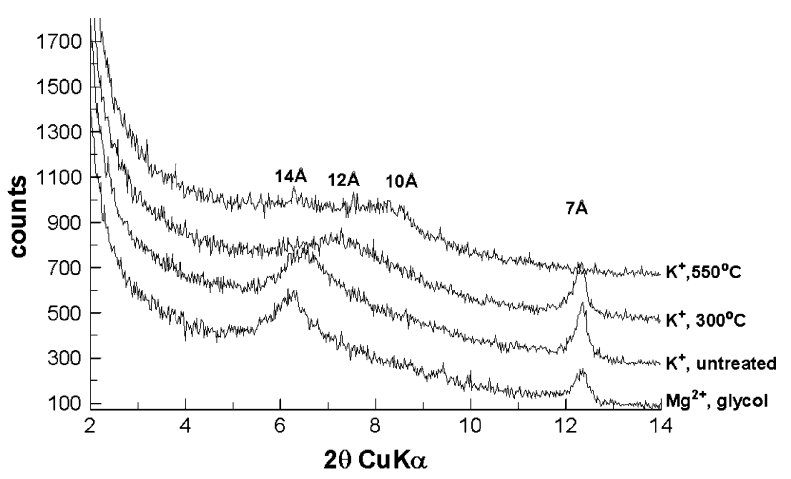

Fig. 4. Diffractograms of selected samples: (a) JI-A; (b) CH3-C; (c) GU-Ah; (d) CH2-A; (e) SI-Ah.

$\mathrm{CH} 2$ samples exhibit similar reflection, while in the $\mathrm{CH} 3$ samples indications for the presence of regular interstratifications are limited to $21 \AA$ reflections in Ksaturated samples. Evidence for irregular interstratifications in the $\mathrm{CH} 2$ pedon are minor reflections in the range of 12.5-13.0 $\AA$ indicating a mica-hydroxy vermiculite structure. Lastly, in the $\mathrm{C}$ horizon of the pedon $\mathrm{CH} 3$, a very distinct reflection shifting from 7.6 to 8.5 and higher $\AA$ values depending on cation type and heating stage, points to an irregular interstratification of a $7 \AA$ mineral (probably kaolinite) and a swelling mineral, probably vermiculite.

In the Central Cordillera, the JI samples contain interstratifications that can be easily identified as micavermiculite interstratifications by their behaviour upon different pretreatments: e.g. complete collapse to $10 \AA$ 
after saturation with $\mathrm{K}$, etc. Interstratifications in the Ah horizon of the GU pedon are similar, but exhibit some hydroxy-interlayering, evidenced by e.g. incomplete collapse after K-saturation.

The various 2:1 clay minerals have been extensively described in the literature as members of a weathering sequence from muscovite, through illite and vermiculite, to eventually smectite (high charge smectite formed by transformation of e.g. vermiculite). Al-hydroxy interlayering may occur at the stage of vermiculite or after further weathering to smectite, giving rise to soil chlorite (e.g. Barnhisel and Bertsch, 1989; McBride, 1994). Regular and irregular interstratifications of the types observed are common in such weathering sequences and generally represent transitional weathering stages (Shoji et al., 1985, Mizota and van Reeuwijk, 1989).

As to the 'other minerals', these are mostly primary minerals such as quartz, cristobalite, feldspar and, in samples from site PD, heulandite (zeolite group). Cristobalite is known to occur in older rocks of volcanic origin in the Andes and in its recent volcanic ashes, and has been reported by Mizota and van Reeuwijk (1989) as characteristic primary mineral for Ecuadorian Andosols. Heulandite is a zeolite mineral that may be an important constituent of volcanoclastic sediments, as encountered in the Tarqui and Saraguro formations. It has been reported from the Western Cordillera SW of Quito (Tripodi, 2002). Gibbsite was not observed in the samples from the Western Cordillera, while hematite lacks in those from the Central Cordillera. As to hematite, this mineral is a common minor constituent of volcanic ashes, in particular those that were very hot when erupted, leading to oxidation of iron compounds at high temperature to produce hematite.

Looking at the results in more detail, the following observations can be made.

In the Western Cordillera, the clay minerals in the topsoil (Ah horizons) are even less crystalline than those in the subsoil, with the exception of SO and PD. In these poorly crystalline topsoils, kaolin minerals are rare or absent and clay fractions are composed of a mixture of non-crystalline compounds, primary minerals from volcanic ash (quartz, cristobalite, hematite) and small amounts of weathered mica (mostly vermiculite) exhibiting more or less prominent hydroxy-Al interlayering.
In the SO profile, contrasts between top and subsoil are minimal. Kaolinite abounds while amorphous material is less abundant, In the PD profile, most remarkable is the presence of heulandite, even in the Ah horizon. Additionally, contents of non-crystalline material are much lower (Table 1), in parallel with the higher crystallinity of the phyllosilicates.

In the Central Cordillera, differences in composition between top and subsoil are small. Kaolinite is invariably rather abundant, but for the rest the composition is quite variable. In the SI profile, gibbsite and cristobalite abound with additionally some chlorite, resulting in an overall rather 'aluminous' assemblage (relatively high $\mathrm{Al} / \mathrm{Si}$ ratio). In the JI and GU profiles, micaceous minerals are much more common (interstratifications with micaillite and vermiculite, and even some illite), but gibbsite is present in the JI profile. Overall, the clay fractions resemble those of profile SO from the Western Cordillera.

The TA profile is from in between the two Cordilleras. It resembles the SO profile and the profiles from the Central Cordillera because of the absence of a distinct contrast between top and subsoil, but contains a relative large amount of amorphous material. With regard to its non-phyllosilicates, it has an intermediate composition with cristobalite and hematite (Western Cordillera), but also some gibbsite (Central Cordillera).

\section{Discussion}

From the earlier studies (see Section 2), general trends in soil development and properties can be inferred. The wet and cold climates of the páramo favour leaching of basic cations and silica released by weathering and a retarded decomposition of soil organic matter. In recent volcanic ashes, these processes are known to lead to the development of non-allophanic Andosols, i.e. Andosols in which the topsoil is low in newly formed allophanes and kaolin minerals and organometallic complexes abound. Subsoils tend to be higher in allophane as reflected by lower $\mathrm{Al}_{\mathrm{p}} / \mathrm{Al}_{\mathrm{o}}$ ratios. This has been ascribed to various causes: a larger supply of silica (resilication), less organic matter and thus lesser complexation, and a further advanced weathering and ageing. The latter 
particularly holds for complex Andosols, i.e. older soils on which more recent volcanic ashes were deposited. Such complex Andosols, which in fact may consist of a series of paleosols, abound in the outer reaches of the volcanoes in Ecuador (Poulenard, 2000; Poulenard et al., 2003). Evidently, 2:1 phyllosilicates in more or less advanced stage of weathering will only occur if the ashes contain primary mica, which is indeed the case in the ashes produced by the Sangay and Tungarahua.

Our results for the páramo soils in the northern part of the Western Cordillera fully comply with the above description and their clay mineralogy thus can be described as classic for non-allophanic Andosols. Further south, in the profiles SO and PD, organometal complexes still dominate over allophane or imogolite, $\mathrm{Al}_{\mathrm{p}} / \mathrm{Al}_{\mathrm{o}}$ ratios being close to unity. This seems to be in conflict with the suite of crystalline minerals observed in these soils: in the SO profile, kaolinite abounds while in the PD profile heulandite occurs, which is a zeolite typical for low-grade metamorphosis or diagenesis (Anthony et al., 1995). Given the lack of contrast in mineralogy between top and subsoil, the most likely explanation is that the bulk of the clay fraction is inherited from the sediment (PD) or represents an older soil (SO) and only minor amounts of recent volcanic ash were deposited. The latter can be easily explained by the larger distance from the volcanoes in the north from which these ashes originate (see Fig. 1).

The geological formations in the Central Cordillera consist of Mesozoic and older rocks. They were affected by slight metamorphosis and intruded by magma to form igneous bodies, explaining the relatively common occurrence of mica and secondary minerals derived from mica through its degradation by weathering. In contrast to the Western Cordillera, on summit levels remnants of deeply and highly weathered regolith occur dating back to the period before the tectonic uplift.

The profiles GU, SI and JI are from the páramo zone, i.e. the higher mountain level where such regoliths are most frequently encountered. Organometallic complexes are present, but in small amounts only. Their genesis cannot be exclusively linked to weathering of recent volcanic ash, since $\mathrm{Al}$ and $\mathrm{Fe}$ may just as well be released from primary and secondary minerals present in the regolith, though at considerably lower rates given the higher stability of the minerals involved, relative to volcanic glass and other, highly weatherable compounds of volcanic rocks. Other indications for the presence of recent volcanic ashes, such as poor crystallinity of the clay fraction and high contents of amorphous material, also lack. In fact, this is to be expected since this Cordillera lies outside the reach of the Sangay and Tungarahua eruptions.

The profiles SI and JI probably are developed in more strongly weathered rock (regolith) than profile GU, which still contains a significant amount of 2:1 minerals (notably muscovite). Given the genesis of these Palaeozoic rocks - more or less metamorphic with local intrusions of acid to intermediate igneous rocks - the alternative explanation for the occurrence of kaolinite and gibbsite - inheritance from these rocks - is extremely unlikely, particularly because of the fair amounts encountered.

As to the TA profile that occurs in an intermediate position, i.e. in between the Central and Western Cordillera and in the border zone of the recent volcanic ashes, its properties are clearly in between those of the Western and the Central Cordillera. Evidently, here too, older weathered regolith must be responsible for the occurrence of gibbsite and fair amounts of kaolinite. Nevertheless, there is some influence of recent volcanic ashes as indicated by the relatively high content of organometallic complexes and also suggested by the slight but distinct differences between top and subsoil.

\section{Conclusions}

Though thick, dark and humic topsoils that have a low bulk density mark all páramo soils in the Paute basin, they exhibit major differences in composition of their clay fraction that can be linked to the extent that Andic properties are developed. These differences can be attributed to differences in parent material, three major types of material being recognized.

The first, connected with non-allophanic Andosols, consists of recent volcanic ashes originating from the Tungarahua and Sangay volcanoes, giving rise to a dominance of organometal complexes and a very minor but distinctive suite of degraded mica's. The second type consists of the various Tertiary and earlier 
formations that constitute the Western and Central Cordilleras. They contain fair amounts of easy weatherable minerals, which very well explains that in soils developed in this parent material that are outside the reach of the ash plumes of the Sangay and Tungarahua organometal complexes are still quite common. However, particularly in the higher parts of the Central Cordillera Tertiary deeply weathered regolith occurs, formed prior to the upheaval of the Cordilleras under humid tropical conditions. This regolith constitutes the third type of parent material being particularly marked by the abundant presence of kaolinite and occurrence of gibbsite. It is this third type of material in which Andic properties of the páramo soils are least developed and on which Histosols occur.

The results demonstrate the major impact of recent volcanic ashes on the clay mineralogy of the páramo soils, even minor ashfalls in the outer reaches of volcanic complexes being sufficient to strongly affect the mineralogy and genesis of these soils. Such phenomenon must be widespread in the Andes and stresses the importance of studies on the distribution and properties of tephra in this region. Another important observation is that outside the reach of volcanic ash plumes, in spite of the very steep, mountainous relief and recent orogenesis, in summit positions relicts from lowland humid tropical regoliths may abound and control the clay mineralogy of these mountain soils.

For high altitude mountain soils and at this catchment scale the clay mineral assemblages found are extremely varied and certainly do not match the idea of the Andes being dominated by Andosols in volcanic ashes with their characteristic clay mineral suite. Furthermore, this highly varied clay mineralogy must lead to significant differences in soil physical properties that are relevant for their behaviour in relation to land use. Our results thus clearly demonstrate the usefulness of this type of hitherto very scarce research for studies on land degradation and related topics.

\section{Acknowledgements}

We like to thank Dr. Felipe Cisneros, director of PROMAS (the Programme for Soil and Water
Management of the Universidad de Cuenca, Ecuador), for logistic help during the study, and Hannele Duyck, Jaime Garrido and Pablo Borja for their intensive help during the field trips. We also thank the Fund for Scientific Research Flanders, which supported W. Buytaert as a researcher.

\section{References}

Anthony, J.W., Bideaux, R.A., Bladh, K.W., Nichols, M.C., 1995. Handbook of mineralogy. Silica \& Silicates, vol. II. Mineral Data Publishing.

Barberi, F., Coltelli, M., Ferrara, G., Innocenti, F., Navarro, J.M., Santacroce, R., 1988. Plio-quaternary volcanism in Ecuador. Geol. Mag. 125, 1-14.

Barnhisel, R.I., Bertsch, P.M., 1989. Chlorites and hydroxyinterlayered vermiculite and smectite. In: Dixon, J.B., Weed, S.B. (Eds.), Minerals in Soil Environments. Soil Science Society of America Book Series, Madison, WI, pp. 729-788.

Bartoli, F., Burtin, G., Herbillon, A.J., 1991. Disaggregation and clay dispersion of oxisols: Na resin, a recommended methodology. Geoderma 49, 301-317.

Borchardt, G., 1989. Smectites. In: Dixon, J.B., Weed, S.B. (Eds.), Minerals in Soils Environments. Soil Science Society of America, Madison, pp. 675-718.

Brown, G., Edwards, B., Omerod, E.C., Weir, A.H., 1972. A simple diffractometer heating stage. Clay Miner. 9, 407-413.

Buytaert, W., 2004. The properties of the soils of the south Ecuadorian páramo and the impact of land use changes on their hydrology. PhD thesis. Katholieke Universiteit Leuven.

Buytaert, W., Deckers, J., Dercon, G., De Bièvre, B., Poesen, J., Govers, G., 2002. Impact of land use changes on the hydrological properties of volcanic ash soils in south Ecuador. Soil Use Manage. 18, 94-100.

Colmet-Daage, F., Cucalon, F., Delaune, M., Gautheyrou, J., Gautheyrou, M., Moreau, B., 1967a. Caractéristiques de quelques sols d'Equateur dérivés de cendres volcaniques: I. Essai de caractérisation des sols des régions tropicales humides. Cahiers-ORSTOM. Pédologie 5, 1-38.

Colmet-Daage, F., Cucalon, F., Delaune, M., Gautheyrou, J., Gautheyrou, M., Moreau, B., 1967b. Caractéristiques de quelques sols d'Equateur dérivés de cendres volcaniques: II. Conditions de formation et d'évolution. Cahiers-ORSTOM. Pédologie 5, 353-392.

Coltorti, M., Ollier, C.D., 2000. Geomorphic and tectonic evolution of the Ecuadorian Andes. Geomorphology 32, 1-19.

Dixon, J.B., Weed, S.B. (Eds.), 1989. Minerals in Soil Environments, second ed. SSSA Book Series, vol. 1. SSSA, Madison, USA.

FAO, M., 1990. Guidelines for Soil Description. Soil Resources, Management and Conservation Service, 3rd ed. FAO, Rome.

FAO/ISRIC/ISSS, 1998. World Reference Base for Soil Resources. Number 84 in World Soil Resources Reports. FAO, Rome.

Hofstede, R.G.M., 1995. Effects of burning and grazing on a Colombian páramo ecosystem. $\mathrm{PhD}$ thesis, Universiteit van Amsterdam. 
Hungerbühler, D., Steinmann, M., Winkler, W., Seward, D., Eguez, A., Peterson, D.E., Helg, U., Hammer, C., 2002. Neogene stratigraphy and Andean geodynamics of southern Ecuador. Earth-Sci. Rev. 57, 75-124.

McBride, M.B., 1994. Environmental Chemistry of Soils. Oxford Univ. Press.

Mizota, C., van Reeuwijk, L.P., 1989. Clay Mineralogy and Chemistry of Soils Formed in Volcanic Material in Diverse Climatic Regions. International Soil Reference and Information Centre, Wageningen.

Monzier, M., Robin, C., Samaniego, P., Hall, M.L., Cotton, J., Mothes, P., Arnaud, N., 1999. Sangay volcano, Ecuador: structural development, present activity and petrology. J. Volcanol. Geotherm. Res. 90, 49-79.

Mothes, P., Hall, M.L., 1991. El paisaje interandino y su formación por eventos volcanicos de gran magnitud. In: Mothes, P. (Ed.), El paisaje volcanico de la sierra Ecuatoriana. Estudios de geografía 4. Colegio de geógrafos del Ecuador, Quito, pp. 10-37.

Parfitt, P.L., Furkert, R.J., 1980. Identification and structure of two types of allophane from volcanic ash soils and tephra. Clays Clay Miner. 28, 328-334.

Parfitt, R.L., Hemni, T., 1980. Structure of some allophanes from New Zealand. Clays Clay Miner. 28, 285-294.

Parfitt, R.L., Kimble, J.M., 1989. Conditions for formation of allophane in soils. Soil Sci. Soc. Am. J. 53, 971-977.

Parfitt, R.L., Wilson, A.D., 1985. Estimation of allophane and halloysite in three sequences of volcanic soils, New Zealand. In: E. Fernandez Caldas, D.H. Yaalon (Eds.), Volcanic soils. CATENA Suppl. 7. Braunschweig. Catena Verlag, Germany. pp. $1-8$.

Poulenard, J., 2000. Les sols des páramos d'Equateur sur couverture pyroclastique. Diversité, génèse et propriétés physiques. PhD thesis. Universite Henry Poincare-Nancy I.

Poulenard, J., Podwojewski, P., Janeau, J.L., Collinet, J., 2001. Runoff and soil erosion under rainfall simulation of Andisols from the Ecuadorian páramo: effect of tillage and burning. Catena 45, 185-207.
Poulenard, J., Podwojewski, P., Herbillon, A.J., 2003. Characteristics of non-allophanic Andisols with hydric properties from the Ecuadorian páramos. Geoderma 117, 267-281.

Sauer, W., 1957. El mapa geológico del Ecuador. Editorial Universitaria, Quito.

Shoji, S., Ito, T., Saigusa, M., Yamada, I., 1985. Properties of nonallophanic Andosols from Japan. Soil Sci. 140, 264-277.

Shoji, S., Nanzyo, M., Dahlgren, R., 1993. Volcanic Ash Soils: Genesis, Properties and Utilisation. Developments in Soil Science, vol. 21. Elsevier, Amsterdam.

Tripodi, D., 2002. The Early Tertiary gold-rich VHMS of La Plata, Western Cordillera, Ecuador. MSc Thesis. Département de Minéralogie, Université de Genève.

Van Ranst, E., Verloo, M., Demeyer, A., Pauwels, J.M., 1999. Manual for the Soil Chemistry and Fertility Laboratory. University of Gent, Gent.

Van Reeuwijk, L.P., 2002. Procedures for soil analysis, 6th ed. International Soil Reference and Information Centre, Wageningen.

Wada, K., 1985. The distinctive properties of andosols. Adv. Soil Sci. 2, 174-223.

Wada, K., 1986. Ando Soils in Japan. Kyushu University Press.

Wada, K., Kakuto, Y., 1985. Embryonic halloysites in Ecuadorian soils derived from volcanic ash. Soil Sci. Soc. Am. J. 49, 1309-1317.

Wilson, M.J., 1987. A Handbook of Determinative Methods in Clay Mineralogy. Blackie, Glasgow.

Winckell, A., Zebrowski, C., Sourdat, M., 1997. Las regiones y paisajes del Ecuador. Geografía básica del Ecuador, Tomo IV Geografía Física, vol. 2, C.E.D.I.G.

Yuan, G., Theng, K.G., Parfitt, R.L., Percival, H.J., 2000. Interaction of allophane with humic acid and cations. Eur. J. Soil Sci. 51, 35-41.

Zehetner, F., Miller, W.P., West, L.T., 2003. Pedogenesis of volcanic ash soils in Andean Ecuador. Soil Sci. Soc. Am. J. 67, 1797-1809. 